Article

\title{
Continuous-Flow Biocatalytic Process for the Synthesis of the Best Stereoisomers of the Commercial Fragrances Leather Cyclohexanol (4-Isopropylcyclohexanol) and Woody Acetate (4-(Tert-Butyl)Cyclohexyl Acetate)
}

\author{
Francesca Tentori ${ }^{1,+}$, Elisabetta Brenna ${ }^{1,2, * \mathbb{D}}$, Michele Crotti $^{1}$, Giuseppe Pedrocchi-Fantoni ${ }^{2}$, \\ Maria Chiara Ghezzi ${ }^{1}$ and Davide Tessaro ${ }^{1}$ (D) \\ 1 Dipartimento di Chimica, Materiali ed Ingegneria Chimica “Giulio Natta”, Politecnico di Milano, Via \\ Mancinelli 7, 20131 Milano, Italy; francesca.tentori@polimi.it (F.T.); michele.crotti@polimi.it (M.C.); \\ mariachiara.ghezzi@polimi.it (M.C.G.); davide.tessaro@polimi.it (D.T.) \\ 2 Istituto di Scienze e Tecnologie Chimiche - CNR, Via Mancinelli 7, 20131 Milano, Italy; \\ giuseppe.pedrocchi@polimi.it \\ * Correspondence: mariaelisabetta.brenna@polimi.it; Tel.: +39-02-2399-3077 \\ + With the exception of the first author, the others are listed in alphabetical order.
}

Received: 21 December 2019; Accepted: 8 January 2020; Published: 10 January 2020

\begin{abstract}
Leather cyclohexanol (4-(isopropyl)cyclohexanol) and woody acetate (4-(tert-butyl)cycloh exyl acetate) are commercialized for functional perfumery applications as mixtures of cis- and trans-isomers. The cis-isomers are more potent odorants than the corresponding trans counterparts, but they are the less favoured products in most of the classical synthetic routes. Known stereoselective routes to cis-4-alkylcyclohexanols are characterized by a high environmental burden and/or troublesome reaction work-up. In this work, we examine the use of commercial alcohol dehydrogenases (ADHs) to produce cis-4-alkylcyclohexanols, including the two derivatives with isopropyl and tert-butyl substituents, by the stereoselective reduction of the corresponding ketones. High conversions and diastereoisomeric excess values were achieved with five of the eighteen tested ADHs. To complete the synthetic approach to woody acetate, Candida antarctica A (CALA) was employed as a catalyst for the enzymatic acetylation of cis-4-(tert-butyl)cyclohexanol. In order to provide a technological upgrade to the production of the most odorous isomers of the two commercial fragrances, we designed a continuous-flow process based on the combination of in-line enzymatic steps with in-line work-up, effectively providing samples of cis-leather cyclohexanol and cis-woody acetate with high diastereoisomeric purity.
\end{abstract}

Keywords: biocatalysis; flow chemistry; cyclohexanones; Candida antarctica A; alcohol-dehydrogenases; fragrances; membranes reactors

\section{Introduction}

Known respectively as leather cyclohexanol and woody acetate, 4-isopropylcyclohexanol (1) and 4-tert-butylcyclohexylacetate (2) (Figure 1) are commercialized as fragrance ingredients for applications in the field of functional perfumery, such as beauty care, soap, laundry care, and household products. The first (Apo Patchone Coeur - IFF; Folrosia - Givaudan) has a diffusive leathery and floral effect, reminiscent of lilac, rose and geranium [1], and it is generally available as a mixture of cis (25\%-35\%) and trans-diastereoisomers (65\%-75\%). The latter (Vertenex- IFF; Lorysia - Firmenich) is sweet, rich, floral, with woody-orris character [2], and it is usually sold as a sum of cis- $(>27 \%)$ and trans-isomers 
(69\%-73\%). Vertenex High Cis is also available with a minimum $68 \%$ of the cis-isomer, because cis-2 has been found to show more valuable odor characteristics than the trans isomer. It is very likely that the same difference does exist for compounds cis- and trans-1.
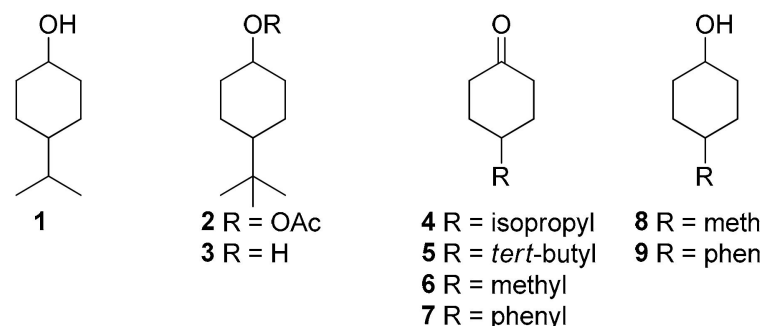

$8 \mathrm{R}=$ methyl

$9 \mathrm{R}=$ phenyl

$7 \mathrm{R}=$ phenyl

Figure 1. Chemical structures of leather cyclohexanol (1), woody acetate (2), and related compounds.

Mixtures of cis- and trans-4-alkylcyclohexanols $\mathbf{1}$ and 3 are usually obtained by liquid-phase hydrogenation of 4-alkylphenols over supported metal catalysts in organic solvent [3-5]. In these conditions, however, the thermodynamically more stable trans- isomer is also formed simultaneously, most frequently as the main product. Good stereoselectivity (de $=58 \%$ ) towards cis-tert-butylcyclohexanol (3) was also obtained by the hydrogenation $\left(\mathrm{H}_{2(\mathrm{~g})} \mathrm{p}=2 \mathrm{MPa}\right)$ of 4-tert-butylphenol over a charcoal-supported rhodium catalyst at $313 \mathrm{~K}$ in supercritical carbon dioxide $\left(\mathrm{scCO}_{2}\right)$ as a solvent [6]. In a further development of this procedure, the addition of hydrochloric acid to the catalytic system was reported to be effective in controlling the stereoselectivity of 4-tert-isopropylphenol hydrogenation [7], and to afford cis-1 with de $=76 \%$.

As for the reduction of the corresponding 4-alkylcyclohexanones 4 and 5 , the use of sterically hindered L-selectride in THF at $-78{ }^{\circ} \mathrm{C}$ was described by Brown [8] to afford cis-3 with de $=93 \%$. The effect of solvent on the stereoselectivity of cyclic ketone reduction by Al-isopropoxydiisobutylalane (DIBAiOPr) has been also investigated. In dichloromethane, DIBAiOPr behaves as a bulky reducing agent, and approaches the carbonyl group along an equatorial trajectory, affording cis-3 with $>10: 1$ stereoselectivity [9]. In 1999, Takasago patented a process for the production of $\mathrm{cis}-3$ with de $=90 \%$ by reduction of ketone 5 with rhodium based-catalysts under high temperature and pressure conditions in the presence of an alkali metal and an alkylenediamine [10].

To our knowledge, the only biocatalytic approach to alcohols $\mathbf{1}$ and $\mathbf{3}$ described in the literature is the reduction of ketones 4 and $\mathbf{5}$ mediated by horse liver dehydrogenase (HLDH) in the presence of stoichiometric NADH. Derivative trans-1 $(\mathrm{de}=48 \%)$ and cis-3 $(\mathrm{de}=94 \%)$ were obtained [11].

Since the availability of commercial ADHs has greatly increased during the last years, we undertook the investigation of these enzymes for the stereoselective reduction of ketones 4 and 5 , in order to achieve high selectivity values towards the corresponding cis-alcohols. The aim of the work was the development of a low energy procedure, operating at room temperature and pressure with renewable catalysts, as a sustainable alternative to known synthetic methods, based on either the use of metal catalysts under $\mathrm{H}_{2}$ pressure or the employment of reducing agents in anhydrous inert solvents at low temperature, requiring troublesome work-up procedures.

For woody acetate, the reduction step was combined with the lipase-mediated acetylation of cis-3 to provide an all-enzymatic route to the fragrance. Furthermore, in order to meet the expectations of a new industrial culture demanding manufacturing processes characterized by flexibility, automation and interconnected production units [12,13], we took up the challenge to apply continuous-flow conditions to this biocatalytic procedure. While synthetic chemistry has been widely involved in flow-mode applications [14-16] in the past decade, biocatalysis has raised its attention to continuous-flow techniques only recently. Biocatalysis could greatly take advantage of this operational mode, especially when a multistep synthesis is involved. As a matter of fact, very different, even incompatible, reaction conditions may be controlled and optimized separately, thus making the coupling of chemical and biocatalytic steps easier. Then, the possibility to couple reaction steps with in-line work-up reduces 
waste and operational complexity in recovering the intermediate to be submitted to the subsequent reaction step [17-20].

Thus intrigued by the great opportunities that flow chemistry delivers to the future of industrial biocatalysis, in this work, we describe the optimization of a highly selective preparation of cis-4-alkylcyclohexanols, employing cis-1 and cis-3 as model target compounds showing commercial interest in the field of synthetic fragrances. We present the development of a continuous-flow process also for cis-2, based on a two-step all-enzymatic procedure, as a case study involving some experimental hurdles, such as the handling of the strongly insoluble ketone 5 and the necessity to combine two reactions (ADH-reduction and lipase-mediated acetylation) characterized by rather incompatible experimental conditions.

\section{Results and Discussion}

\subsection{Screening of ADH-mediated Reduction of 4-alkycyclohexanones 4-7}

The biocatalytic reduction of differently substituted 4-alkylcyclohexanones by ADHs has been rarely documented [11]. With the aim of finding an enzyme providing complete reduction to the corresponding cis-diastereoisomer and, at the same time, of better understanding the influence of the substituent in position 4, the four commercially available compounds 4-7 were submitted to ADH-mediated reduction, using a commercial kit of 18 enzymes. $\mathrm{NAD}(\mathrm{P}) \mathrm{H}$ cofactor was employed in catalytic amount and regenerated using glucose dehydrogenase (GDH from Bacillus megaterium), in the presence of glucose as a sacrificial cosubstrate. DMSO was employed as a cosolvent. For each ADH, the optimal $\mathrm{pH}$ value suggested by the producer was employed. The product distribution after $18 \mathrm{~h}$ reaction time was determined by GC/MS analysis.

Considering that, in general, at least half of the ADHs of the kit were almost ineffective, we gathered the best results in Figure 2, providing conversions and diastereoisomeric excess (de) values for the reactions mediated by the six most active ADHs (EVO30, 200, 441, 270, 420, 440) in $18 \mathrm{~h}$ reaction time. The complete results of this screening are reported in Supplementary Materials Table S1.

These results show a broad variety of behavior in terms of conversion and diastereoisomeric excess. As a general view, ketone 6, bearing the smallest substituent (methyl) in position 4, was modestly accepted by most of the ADHs of the kit, hardly reaching a conversion of $80 \%$ in most cases. With the other substituents, although much bulkier than methyl, conversions were surprisingly almost complete when submitted to the most active ADHs.

More interestingly, with five of the six most active ADHs (EVO30, 200, 441, 270, 420), the thermodynamically less stable cis isomers of the four alcohols were obtained, providing in general good de values. In particular, in the reduction of substrates 4 and 5, ADHs EVO30, 200, 441, 270 and 420 afforded complete reduction with the formation of cis-1 and cis-3 showing de $=72 \%-88 \%$ and $66 \%-99 \%$, respectively. ADH 440 completely reduced both 4 and 5 to the trans isomer with de $=87 \%$ and $>99 \%$, respectively. The other twelve ADHs reduced the two substrates with modest conversions, to afford mixtures of the two isomers (data reported in Supplementary Materials Table S1). 

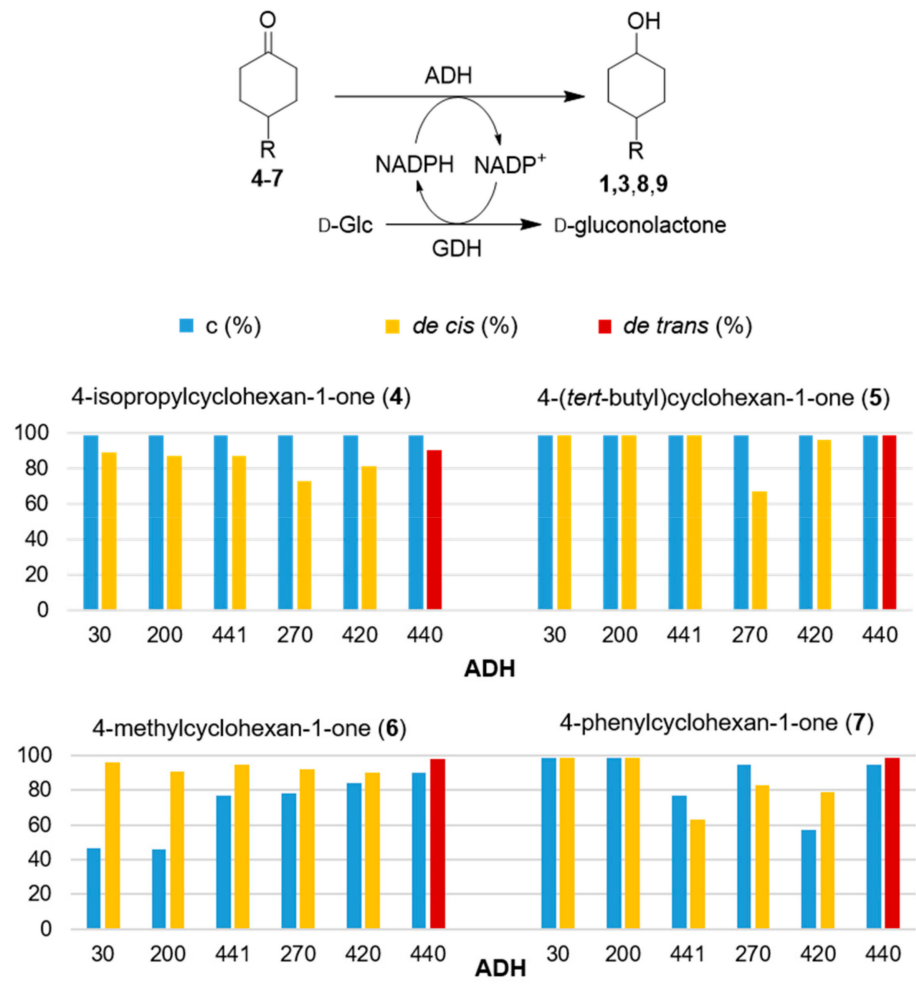

Figure 2. Screening of ADH-mediated reduction of 4-alkycyclohexanones 4-7 to 4-alkycyclohexanols $1,3,8,9$. Results are reported only for the six most performant ADHs (for the complete results see Supplementary Materials). $5 \mathrm{mM}$ substrate, $20 \mathrm{mM}$ glucose, $\mathrm{ADH}\left(200 \mu \mathrm{g} \mathrm{mL}^{-1}\right), \mathrm{GDH}\left(5 \mathrm{U} \mathrm{mL}^{-1}\right)$, $\mathrm{NADH}$ and $\mathrm{NADP}^{+}(0.1 \mathrm{mmol}$ each $), 1 \%$ DMSO, phosphate buffer $\mathrm{pH} 7.0,30^{\circ} \mathrm{C}, 18 \mathrm{~h}$; conversion (c\%) and diastereoisomeric excess $(d e \%)$ calculated by GC/MS.

\subsection{Screening of lipase-mediated Acetylation of cis-3 to Afford Derivative cis-2}

After having obtained cis-3 with high de value by ADH-mediated reduction, we thought to employ a second biocatalytic step to complete the synthetic approach to the corresponding high cis-acetyl ester derivative $\mathbf{2}$, and obtain a product showing better olfactory properties than the commercial formulation, through an all-enzymatic procedure. The classical acetylation process employing acetic anhydride or acetyl chloride in organic solvent in the presence of an equimolar amount of pyridine or triethylamine is without any doubt economic and easy to perform but shows several negative effects on the sustainability of the reaction. Chlorinated solvents are usually employed with excess of acylating agents, and heating or long reaction time are required. The loss of one mol of either acetic acid or chloride per mol of ester, together with the loss of the tertiary base employed for its neutralization, negatively influences the atom economy of the transformation. Furthermore, the aqueous effluents coming from work-up have to be properly treated before final disposal.

Thus, we investigated the lipase - mediated acetylation of derivative cis-3 in methyl tert-butyl ether (MTBE) as a solvent, in the presence of vinyl acetate as an acyl donor [21,22] in $18 \mathrm{~h}$ reaction time. Five different lipases were tested, and Candida antarctica lipase A (CALA) was selected as the best performer (Table 1). 
Table 1. Screening of lipase-mediated acetylation of cis-3. ${ }^{1}$.

Lipase
Candida rugosa lipase
Candida antarctica lipase A
Candida antarctica lipase B

CALA was found to be effective also in the acylation of trans-3, affording $85 \%$ conversion in $18 \mathrm{~h}$ reaction time.

\subsection{Semi-Preparative Scale Preparation of cis-1 and cis-2 and Olfactory Evaluation}

In order to obtain an acceptable quantity of cis-1 and cis-2, two semi-preparative reductions were carried out on $500 \mathrm{mg}$ of ketones 4 and 5. 2-Propanol was used not only as a co-solvent, but also to regenerate the cofactor in the reduced form, thus avoiding the recycling system based on GDH and glucose employed in preliminary investigations. Substrates $\mathbf{4}$ and $\mathbf{5}$ were dissolved in 2-propanol (2.2 $\mathrm{mL}$ on a total volume of $40 \mathrm{~mL}$ ), using ADH 200 as a catalyst $(10 \mathrm{mg})$, in the presence of a catalytic quantity of NADH $(10 \mathrm{mg})$. After complete conversion in $24 \mathrm{~h}$ reaction time, derivatives cis- $\mathbf{1}$ (de = $87 \%$ ) and cis-3 (de > 99\%) were isolated in 91 and 95\% yield, respectively, by filtration of the enzyme and solvent removal by in vacuo distillation.

Alcohol cis-3 (450 mg) was submitted to CALA-mediated acetylation (150 mg), in MTBE as a solvent $(9 \mathrm{~mL})$, in the presence of vinyl acetate $(1 \mathrm{~mL})$. Acetylation was complete after $24 \mathrm{~h}$ and acetate derivative cis-2 was obtained in 95\% isolated yields and high diastereoisomeric purity (de $>99 \%$ ).

The same procedure was used for a semi-preparative production of the trans isomers of compounds 1 and 3. In this case, ADH 440 was employed, being the only active ADH providing quantitative conversion into the trans isomers. Trans-3 was then converted into trans-2 by CALA-mediated acetylation.

The samples of cis- and trans-1 and cis- and trans-2 were submitted to bulb-to-bulb distillation, then their odor properties were evaluated by professional perfumers at Givaudan. The results are reported in Table 2.

Table 2. Odour description of samples cis- and trans-1, cis- and trans-2.

\begin{tabular}{ccc}
\hline Compound (de\%) & $\begin{array}{c}\text { Odour Threshold } \\
\text { (ng/L air) }\end{array}$ & Title 3 \\
\hline cis-1 (87) & 13 & $\begin{array}{c}\text { floral animalic, phenolic - leathery earthy, tea tree, } \\
\text { p-cresol, green, folrosia, slightly medicinal } \\
\text { floral animalic, leathery, green, folrosia, less green } \\
\text { and leathery than the cis isomer, softer, oilier, and } \\
\text { more pronounced floral. }\end{array}$ \\
cis-2 (>99) & 14.8 & $\begin{array}{c}\text { floral fruity, reminiscent of red fruits, red berries, } \\
\text { dry, woody with aspects of Koavone and } \\
\text { Isoraldein, and slight pear facets. }\end{array}$ \\
trans-2 $(>99)$ & 110 & $\begin{array}{c}\text { Floral, oily, muguet, slightly agrestic, clearly } \\
\text { weaker than the cis-isomer }\end{array}$ \\
\hline
\end{tabular}


The odour description highlights the difference between cis and trans isomers. Cis-1 is almost five times more potent than trans-1, and for the two isomers of derivative $\mathbf{2}$ the difference in odour threshold is even much more pronounced.

\subsection{Continuous-Flow Processes}

The successive step was the optimization of these synthetic sequences in continuous-flow mode. Although the preferential way for implementing biocatalytic continuous-flow processes goes through biocatalyst immobilization with several positive effects on enzyme stability and reusability [23,24], we thought more convenient to avoid the immobilization of a commercial enzyme with unknown characteristics and limited availability. As an alternative to obtain enzyme confinement inside the process, an ultrafiltration system was adopted: a membrane entraps the enzyme inside the reactor (kept under stirring), while reagents and products are continuously moved in and out, according to the CSTR model.

For the continuous-flow production of leather alcohol cis-1 (Figure 3), a phosphate buffer solution $(100 \mathrm{mM}, \mathrm{pH} 7)$ of ketone $4(10 \mathrm{mM})$ and NADH $(0.2 \mathrm{mM})$ was fed to a jacketed membrane reactor $(12 \mathrm{~mL})$ kept at $30^{\circ} \mathrm{C}$, at a flow rate of $200 \mu \mathrm{L} \mathrm{min}^{-1}$. In order to achieve complete substrate dissolution, a high amount of 2-propanol (20\%) was required. Among ADHs showing high selectivity for the cis-isomer, ADH200 was chosen for being active in presence of up to 30\% 2-propanol. Subsequently, $3 \mathrm{mg}$ of $\mathrm{ADH}$ were loaded in the chamber and confined by a regenerated cellulose membrane (cut-off $5 \mathrm{kDa}$ ). Complete conversion was reached at the reactor outlet after $60 \mathrm{~min}$ residence time. Then, the reaction solution was connected to an organic solvent flow at a flowrate of $200 \mu \mathrm{L} \mathrm{min}^{-1}$ by means of a tee piece assembly, to carry out in-line extraction. Hexane was chosen for this extraction process. As a matter of fact, high 2-propanol content represents an issue for phase separation through Zaiput ${ }^{\circledR}$ membrane devices: the highest the interfacial tension between the two phases, the more performant is the separation. Since a $20 \%$ of 2-propanol causes a drop in water surface tension [25], $n$-hexane (the most hydrophobic among common organic solvents, i.e., the one with the highest interfacial tension with water) was found to be the best candidate for a satisfactory separation. The segmented water-hexane flow was then directed to Zaiput ${ }^{\circledR}$ system. The ${ }^{1} \mathrm{H}-\mathrm{NMR}$ analysis of the hexane solution recovered from the in-line extraction showed the presence of $2 \%$ of the starting 2-propanol, besides the desired alcohol cis-1. Evaporation under reduced pressure gave compound cis-1 with an isolation yield of $90 \%$. In order to evaluate process stability, the enzymatic reduction was run for $24 \mathrm{~h}$, showing after this period a slight decrease of conversion to a final value of $80 \%$ (GC/MS).

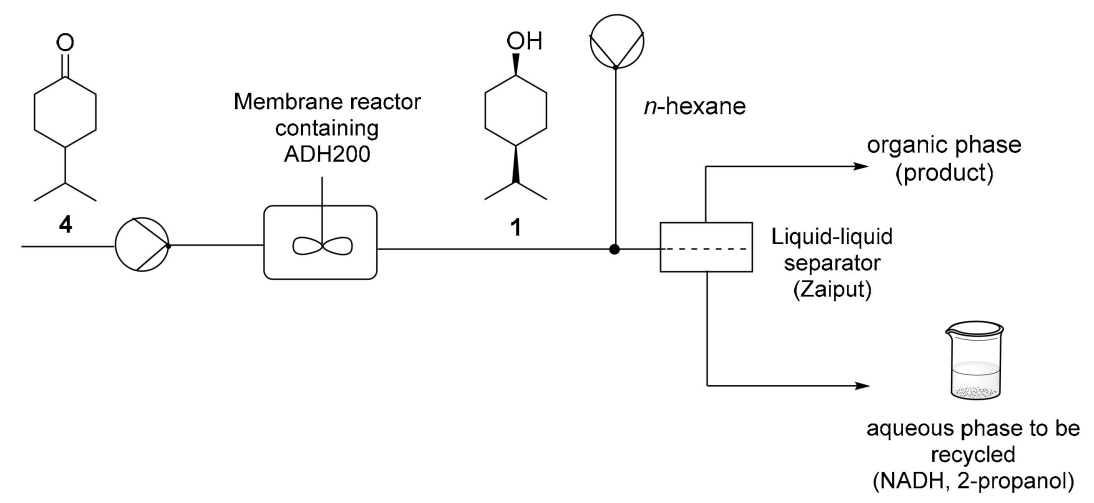

Figure 3. Continuous-flow process for the synthesis of leather alcohol cis-1.

In order to minimize NADH process consumption, we collected the corresponding aqueous phase (containing NADH and most of 2-propanol) with the aim to verify whether it could be recycled inside the system. Thus, after collection, the starting ketone $\mathbf{4}$ and the amount of 2-propanol lost with hexane extraction were added to the aqueous phase and the solution was re-fed to the membrane reactor. The aqueous phase recovered from extraction $(100 \mathrm{~mL})$ was submitted to enzymatic reduction and 
$n$-hexane extraction twice for $8 \mathrm{~h}$ and no significant loss of conversion was observed, neither the first nor the second time.

For the synthesis of acetate cis-2 the first step of ketone reduction was performed according to the same conditions described for the conversion of derivative $\mathbf{4}$ into cis-1 (Figure 4). The combination of this ADH-reduction with lipase-acetylation raised some concerns about the in-line work-up procedure, because the two enzymatic steps occur in different reaction media (respectively buffer and organic solvent), and, moreover, 2-propanol (used in high amount in the first step) is detrimental to CALA [26] and competes with cis-3 in the acetylation reaction. However, the in-line hexane extraction described for compound cis-1 was found to be effective also in this case to solve these issues. In-line separation made the organic phase easily available for the subsequent enzymatic acetylation, with most of 2-propanol remaining in the water phase. Aqueous and organic phases were mixed by using a segmented biphasic flow, and phase separation was achieved using a commercial in-line membrane separator Zaiput ${ }^{\circledR}$. Vinyl acetate was added after phase separation $\left(100 \mu \mathrm{L} \mathrm{min}^{-1}\right)$.

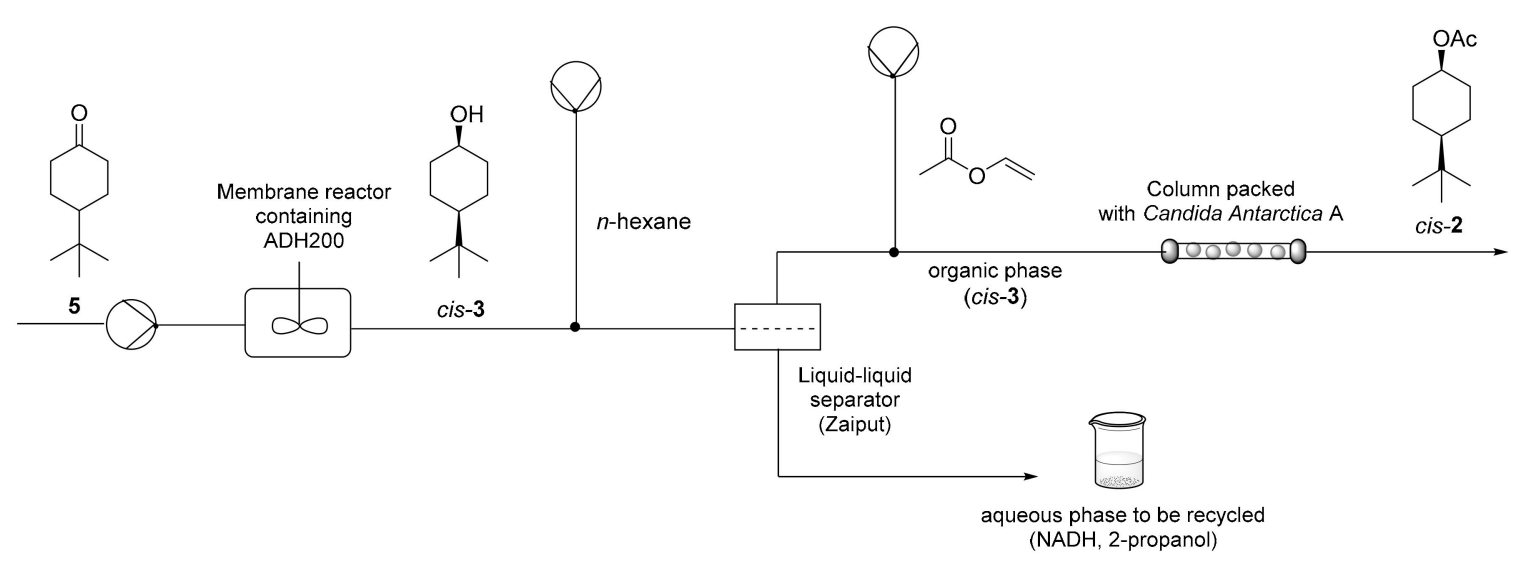

Figure 4. Continuous-flow process for the synthesis of woody acetate cis-2.

For the enzymatic acetylation of compound cis-3, the commercial form of CALA, which is sold as an immobilized enzyme, allowed us to easily set up a packed bed reactor (PFR-like reactor). The column reactor was filled with $500 \mathrm{mg}$ of CALA, which had been previously swelled overnight in hexane. The acetylation step provided $85 \%$ conversion (GC/MS) of cis-3 into cis-2 at the outlet with a residence time of $11 \mathrm{~min}$ : acetate derivative cis-2 was recovered by solvent evaporation with an isolated yield of $81 \%$. Also, in this case, as already described for the production of alcohol 1, the aqueous phase containing NADH and most of 2-propanol was collected and, after substrate 5 addition, reused in the membrane reactor.

When the whole process was run for $24 \mathrm{~h}$, the conversion of ketone 5 into alcohol cis-3 slightly decreased to a final value of $80 \%$ (GC/MS), while lipase acetylation maintained a constant value of $85 \%$ (GC/MS) for all the reaction time.

\section{Materials and Methods}

\subsection{General Materials and Analytical Methods}

Compound 4 (Fluorochem, Hadfield, United Kingdom) and compounds 5-7 (TCI Europe N.V., Zwijndrecht, Belgium) were purchased from Zentek srl (Milan, Italy). All other chemicals and solvents were purchased from Merck (Merck Life Science S.r.l., Milan, Italy) and used without further purification. TLC analyses were performed on Merck Kieselgel 60 F254 plates purchased from Merck. The continuous flow reactions were performed using an E-Series Integrated Flow Chemistry system from Vapourtec (Alfatech S.P.A., Genoa, Italy) equipped with Omnifit glass columns (6.6 $\mathrm{mm}$ i.d. $\times 150 \mathrm{~mm}$ length). As membrane reactor, an ultrafiltration chamber was employed (63.5 $\mathrm{mm}$ i.d.). Ultrafiltration chamber was equipped with a magnetic stirrer reducing the available volume from 
$20 \mathrm{~mL}$ (empty volume) to $12 \mathrm{~mL}$ (effective volume). Membranes for ultrafiltration (regenerated cellulose membranes, $63.5 \mathrm{~mm}$ i.d., $5 \mathrm{kDa}$ cut-off) were purchased from Merck. Liquid-liquid separator Zaiput ${ }^{\circledR}$ was purchased from Zaiput Flow Technologies (Waltham, MA, USA) and employed in combination with hydrophobic OP-900 membranes from the same supplier. ${ }^{1} \mathrm{H}$ and ${ }^{13} \mathrm{C}$ NMR spectra were recorded on a 400 or $500 \mathrm{MHz}$ spectrometer in $\mathrm{CDCl}_{3}$ solution at r.t. The chemical shift scale was based on internal tetramethylsilane. GC/MS analyses were performed using a HP-5MS column (30 m $\times 0.25 \mathrm{~mm} \times 0.25 \mu \mathrm{m}$, Agilent Technologies Italia Spa (Cernusco sul Naviglio, Italy)). The following temperature program was employed: $60^{\circ} \mathrm{C}(1 \mathrm{~min}) / 6^{\circ} \mathrm{C} \mathrm{min}-1 / 150{ }^{\circ} \mathrm{C}(1 \mathrm{~min}) / 12^{\circ} \mathrm{C} \mathrm{min}^{-1} / 280^{\circ} \mathrm{C}$ (5 min).

\subsection{Sources of Enzymes}

GDH from Bacillus megaterium DSM509 (DSM, Heerlen, the Netherlands) was overexpressed in E. coli BL21 (DE3) strains harbouring the plasmid pKTS-GDH prepared according to standard molecular biology techniques. The enzyme was produced and purified, as described in the Supplementary Materials. Candida antarctica lipase A was purchased from Merck. The complete set of ADHs was purchased from Evoxx (Monheim am Rhein, Germany).

\subsection{General Procedure for the ADH-mediated reduction of cyclohexanones 4-7 (Screening Scale)}

The suitable substrate $(5 \mu \mathrm{mol})$, dissolved in DMSO $(10 \mu \mathrm{L})$, was added to a phosphate buffer solution ( $1 \mathrm{~mL}, 50 \mathrm{mM}, \mathrm{pH} 7)$ containing glucose $(20 \mathrm{mM}, 4$ eq. with respect to the substrate), NADH and $\mathrm{NADP}^{+}\left(0.1 \mathrm{mM}\right.$ each), GDH $\left(5 \mathrm{U} \mathrm{mL}^{-1}\right)$, and an ADH $\left(200 \mu \mathrm{g} \mathrm{mL}^{-1}\right)$. The mixture was kept for $18 \mathrm{~h}$ in an orbital shaker $\left(160 \mathrm{rpm}, 30^{\circ} \mathrm{C}\right)$. The solution was extracted with EtOAc $(3 \times 500 \mu \mathrm{L})$ and centrifuged (15000 g, $1.5 \mathrm{~min}$ ). The combined organic phases were dried over $\mathrm{Na}_{2} \mathrm{SO}_{4}$ and analyzed.

\subsection{General Procedure for Lipase-Mediated Acetylation of 4-(tert-butyl)cyclohexan-1-ol (cis-3)} (Screening Scale)

Alcohol cis-3 (50 mg.mL ${ }^{-1}$ final concentration) was dissolved in a solution of MTBE and vinyl acetate $(10 \% \mathrm{v} / \mathrm{v})$. A suitable lipase was added $\left(10 \mathrm{mg} \cdot \mathrm{mL}^{-1}\right)$. The reaction mixture was shaken $\left(160 \mathrm{rpm}, 30^{\circ} \mathrm{C}\right)$ for $18 \mathrm{~h}$ in an orbital shaker.

\subsection{General Procedure for cis-selective ADH-Mediated Reduction of Cyclohexanones 4-7 (Semi-preparative Scale)}

The suitable substrate $(500 \mathrm{mg})$, dissolved in 2-propanol $(2.2 \mathrm{~mL})$, was added to a phosphate buffer solution (50 mM, pH 7) for a total volume of $40 \mathrm{~mL}$ together with ADH200 (10 mg) and NADH $(10 \mathrm{mg})$. The mixture was kept for $24 \mathrm{~h}$ in an orbital shaker $\left(160 \mathrm{rpm}, 30^{\circ} \mathrm{C}\right)$, then extracted with EtOAc $(3 \times 40 \mathrm{~mL})$. The combined organic phases were dried over $\mathrm{Na}_{2} \mathrm{SO}_{4}$ and concentrated in vacuo to afford the corresponding alcohol derivative without the need for further purification except for compound cis-8.

\subsubsection{Cis-4-isopropylcyclohexan-1-ol (cis-1)}

From compound 4 (500 mg, $3.57 \mathrm{mmol})$, derivative cis-1 was obtained $(461 \mathrm{mg}, 91 \%$, de $=87 \%$ ): ${ }^{1} \mathrm{H} \mathrm{NMR}\left(\mathrm{CDCl}_{3}, 400 \mathrm{MHz}\right)$ [5]: $\delta=3.99(\mathrm{~m}, 1 \mathrm{H}, \mathrm{CHOH}), 1.79-1.72(\mathrm{~m}, 2 \mathrm{H}$, hydrogens of cyclohexane ring), 1.53-1.41 (m, 7H, hydrogens of cyclohexane ring), 1.09-1.02 $\left(\mathrm{m}, 1 \mathrm{H}, \mathrm{CH}\left(\mathrm{CH}_{3}\right)_{2}\right), 0.88(\mathrm{~d}, 6 \mathrm{H}$, $\left.J=6.8 \mathrm{~Hz}, \mathrm{C}\left(\mathrm{CH}_{3}\right)_{2}\right) .{ }^{13} \mathrm{C} \mathrm{NMR}\left(\mathrm{CDCl}_{3}, 100.6 \mathrm{MHz}\right): \delta=66.6,43.4,32.7,32.0,23.7,19.9$. GC/MS (EI) $\mathrm{T}_{\mathrm{r}}=10.23 \mathrm{~min}: \mathrm{m} / \mathrm{z}(\%)=141\left(\mathrm{M}^{+}-1,1\right), 124(25), 109$ (25), 95 (10), 81 (100). Compound cis-1 was submitted to bulb-to-bulb distillation $\left(85-88^{\circ} \mathrm{C}, 10 \mathrm{mmHg}\right)$ to obtain a sample for olfactory evaluation.

\subsubsection{Cis-4-(tert-butyl)cyclohexan-1-ol (cis-3)}

From compound 5 (500 mg, $3.25 \mathrm{mmol}$ ), derivative cis-3 was obtained ( $481 \mathrm{mg}$, 95\%, de > 99\%): ${ }^{1} \mathrm{H}$ NMR ( $\left.\mathrm{CDCl}_{3}, 400 \mathrm{MHz}\right)$ [27]: $\delta=4.03(\mathrm{~m}, 1 \mathrm{H}, \mathrm{CHOH}), 1.85-1.81(\mathrm{~m}, 2 \mathrm{H}$, hydrogens of cyclohexane 
ring), 1.56-1.31 (m, $6 \mathrm{H}$, hydrogens of cyclohexane ring), 1.02-0.96 $\left(\mathrm{m}, 1 \mathrm{H}, \mathrm{CH}-\mathrm{C}\left(\mathrm{CH}_{3}\right)_{3}\right), 0.86(\mathrm{~s}, 9 \mathrm{H}$, $\left.\mathrm{C}\left(\mathrm{CH}_{3}\right)_{3}\right) ;{ }^{13} \mathrm{C}$ NMR $\left(\mathrm{CDCl}_{3}, 100.6 \mathrm{MHz}\right)$ [27]: $\delta=66.0,48.2,33.6,32.6,27.6,21.1 ; \mathrm{GC} / \mathrm{MS}(\mathrm{EI}) \mathrm{t}_{\mathrm{r}}=$ $11.52 \mathrm{~min}: \mathrm{m} / \mathrm{z}(\%)=156\left(\mathrm{M}^{+}, 1\right), 123(25), 99(25), 81(60), 67(67), 57(100)$.

\subsubsection{Cis-4-methylcyclohexan-1-ol (cis-8)}

From compound 6 (500 mg, $4.46 \mathrm{mmol}$ ), derivative cis-8 was obtained after silica gel column chromatography using hexane and ethyl acetate as eluents $(462 \mathrm{mg}, 40 \%$, de $=91 \%):{ }^{1} \mathrm{H} \mathrm{NMR}\left(\mathrm{CDCl}_{3}\right.$, $400 \mathrm{MHz})$ [28]: $\delta=3.93(\mathrm{~m}, 1 \mathrm{H}, \mathrm{CHOH}), 1.75-1.31(\mathrm{~m}, 9 \mathrm{H}$, hydrogens of cyclohexane ring), $0.91(\mathrm{~d}, 3 \mathrm{H}$, $\left.J=6.2 \mathrm{~Hz}, \mathrm{CH}_{3}\right) ;{ }^{13} \mathrm{C} \mathrm{NMR}\left(\mathrm{CDCl}_{3}, 100.6 \mathrm{MHz}\right)$ [28]: $\delta=67.1,32.4,31.3,29.2,21.8$; GC/MS (EI) tr $=$ $5.54 \mathrm{~min}: \mathrm{m} / \mathrm{z}(\%)=114(\mathrm{M}+, 5), 96(20), 81(39), 70(34), 57(100)$.

\subsubsection{Cis-4-phenylcyclohexan-1-ol (cis-9)}

From compound 7 (500 mg, $2.87 \mathrm{mmol}$ ), derivative cis-9 was obtained (450 mg, 89\%, de > 99\%): ${ }^{1} \mathrm{H}$ NMR ( $\left.\mathrm{CDCl}_{3}, 400 \mathrm{MHz}\right)$ [29]: $\delta=7.32-7.17(\mathrm{~m}, 5 \mathrm{H}, \mathrm{ArH}), 4.14(\mathrm{~m}, 1 \mathrm{H}, \mathrm{CHOH}), 2.54(\mathrm{~m}, 1 \mathrm{H}, \mathrm{CH}-\mathrm{Ph})$, $1.96-1.85\left(\mathrm{~m}, 4 \mathrm{H}, 2 \mathrm{CH}_{2}\right), 1.73-1.64\left(\mathrm{~m}, 4 \mathrm{H}, 2 \mathrm{CH}_{2}\right) ;{ }^{13} \mathrm{C} \mathrm{NMR}\left(\mathrm{CDCl}_{3}, 100.6 \mathrm{MHz}\right)$ [29]: $\delta=147.4,128.4$, $126.9,126.0,65.7,43.9,33.1,27.8 ; \mathrm{GC} / \mathrm{MS}(\mathrm{EI}) \mathrm{t}_{\mathrm{r}}=19.63 \mathrm{~min}: \mathrm{m} / \mathrm{z}(\%)=176\left(\mathrm{M}^{+}, 58\right), 158(25), 143(35)$, 129 (30), 117 (60), 104 (100), 91 (63).

3.6. General Procedure for Trans-Selective ADH-Mediated Reduction of Cyclohexanones 4-7 (Semi-preparative Scale)

The suitable substrate $(500 \mathrm{mg})$ dissolved in 2-propanol $(2.2 \mathrm{~mL})$ was added to a phophate buffer solution (50 mM, pH 7) for a total volume of $40 \mathrm{~mL}$ together with ADH440 (10 mg) and NADH (10 mg). The mixture was kept for $24 \mathrm{~h}$ in an orbital shaker $\left(160 \mathrm{rpm}, 30^{\circ} \mathrm{C}\right)$. The solution was extracted with EtOAc $(3 \times 40 \mathrm{~mL})$. The solution was extracted with EtOAc $(3 \times 40 \mathrm{~mL})$. The combined organic phases were dried over $\mathrm{Na}_{2} \mathrm{SO}_{4}$ and concentrated in vacuo to afford the corresponding alcohol derivative without the need for further purification, except for compounds trans-8 and trans-9.

\subsubsection{Trans-4-isopropylcyclohexan-1-ol (trans-1)}

From compound 4 (500 mg, $3.57 \mathrm{mmol}$ ), derivative trans -1 was obtained $(450 \mathrm{mg}, 89 \%$, de $=87 \%$ ): ${ }^{1} \mathrm{H}$ NMR $\left(\mathrm{CDCl}_{3}, 400 \mathrm{MHz}\right)[5]: \delta=3.53(\mathrm{~m}, 1 \mathrm{H}, \mathrm{CHOH}), 2.02-1.96(\mathrm{~m}, 2 \mathrm{H}$, hydrogens of cyclohexane ring, 1.78-1.68 $(\mathrm{m}, 2 \mathrm{H}$, hydrogens of cyclohexane ring), 1.48-1.35 $(\mathrm{m}, 1 \mathrm{H}$, hydrogen of cyclohexane ring), 1.27-1.18 (m, $2 \mathrm{H}$, hydrogens of cyclohexane ring), 1.08-0.98 $(\mathrm{m}, 3 \mathrm{H}$, hydrogens of cyclohexane ring $\left.+\mathrm{CH}\left(\mathrm{CH}_{3}\right)_{2}\right), 0.86\left(\mathrm{~d}, 6 \mathrm{H}, J=6.8 \mathrm{~Hz}, \mathrm{C}\left(\mathrm{CH}_{3}\right)_{2}\right) \cdot{ }^{13} \mathrm{C} \mathrm{NMR}\left(\mathrm{CDCl}_{3}, 100.6 \mathrm{MHz}\right): \delta=70.4,42.9,35.3$, 32.2, 27.7, 19.7; GC/MS (EI) $\mathrm{t}_{\mathrm{r}}=10.59 \mathrm{~min}: \mathrm{m} / \mathrm{z}(\%)=141\left(\mathrm{M}^{+}-1,1\right), 124(25), 109$ (30), 95 (10), $81(100)$. Compound trans-1 was submitted to bulb-to-bulb distillation $\left(90-95^{\circ} \mathrm{C}, 10 \mathrm{mmHg}\right)$ to obtain a sample for olfactory evaluation.

\subsubsection{Trans-4-(tert-butyl)cyclohexan-1-ol (trans-3)}

From compound 5 (500 mg, $3.25 \mathrm{mmol})$, derivative trans-3 was obtained ( $460 \mathrm{mg}, 91 \%$, de $>99 \%)$ : ${ }^{1} \mathrm{H} \mathrm{NMR}\left(\mathrm{CDCl}_{3}, 400 \mathrm{MHz}\right)$ [27]: $\delta=3.51(\mathrm{~m}, 1 \mathrm{H}, \mathrm{CHOH}), 2.04-1.98(\mathrm{~m}, 2 \mathrm{H}$, hydrogens of cyclohexane ring), 1.81-1.76 $(\mathrm{m}, 2 \mathrm{H}$, hydrogens of cyclohexane ring), 1.30-0.97 $(\mathrm{m}, 5 \mathrm{H}$, hydrogens of cyclohexane ring), 0.85 (s, 9H, $\left.\mathrm{C}\left(\mathrm{CH}_{3}\right)_{3}\right) ;{ }^{13} \mathrm{C} \mathrm{NMR}\left(\mathrm{CDCl}_{3}, 100.6 \mathrm{MHz}\right)$ [27]: $\delta=71.4,47.4,36.3,32.4,27.8,25.8$; GC/MS (EI) $\mathrm{t}_{\mathrm{r}}=11.82 \mathrm{~min}: \mathrm{m} / \mathrm{z}(\%)=138\left(\mathrm{M}^{+}-18,13\right), 123(27), 81(47), 67(40), 57(100)$.

\subsubsection{Trans-4-methylcyclohexan-1-ol (trans-8)}

From compound 6 ( $500 \mathrm{mg}, 4.46 \mathrm{mmol})$, derivative cis- 8 was obtained after silica gel column chromatography using hexane and ethyl acetate as eluents $(457 \mathrm{mg}, 90 \%$, de $=98 \%):{ }^{1} \mathrm{H} \mathrm{NMR}\left(\mathrm{CDCl}_{3}\right.$, $400 \mathrm{MHz})$ [28]: $\delta=3.53\left(\mathrm{tt}, 1 \mathrm{H}, J_{1}=10.8 \mathrm{~Hz}, J_{2}=4.3 \mathrm{~Hz}, \mathrm{CHOH}\right), 1.99-1.88(\mathrm{~m}, 2 \mathrm{H}$, hydrogens of cyclohexane ring), $1.74-1.65(\mathrm{~m}, 2 \mathrm{H}$, hydrogens of cyclohexane ring), $1.39-0.89(\mathrm{~m}, 5 \mathrm{H}$, hydrogens of 
cyclohexane ring), $0.87\left(\mathrm{~d}, 3 \mathrm{H}, J=6.5 \mathrm{~Hz}, \mathrm{CH}_{3}\right) ;{ }^{13} \mathrm{C} \mathrm{NMR}\left(\mathrm{CDCl}_{3}, 100.6 \mathrm{MHz}\right)$ [28]: $\delta=70.9,35.6,33.4$, 31.9, 22.0; GC/MS (EI) $\mathrm{t}_{\mathrm{r}}=5.56 \mathrm{~min}: \mathrm{m} / \mathrm{z}(\%)=113\left(\mathrm{M}^{+}-1,1\right), 96(15), 81(54), 70$ (46), 67 (27), $57(100)$.

3.6.4. Trans-4-phenylcyclohexan-1-ol (trans-9)

From compound 7 (500 mg, $2.87 \mathrm{mmol})$, derivative cis-9 was obtained after silica gel column chromatography using hexane and ethyl acetate as eluents $(440 \mathrm{mg}, 87 \%$, de $>99 \%):{ }^{1} \mathrm{H} \mathrm{NMR}\left(\mathrm{CDCl}_{3}\right.$, $400 \mathrm{MHz})$ [29]: $\delta=7.31-7.16(\mathrm{~m}, 5 \mathrm{H}, \mathrm{ArH}), 3.68(\mathrm{~m}, 1 \mathrm{H}, \mathrm{CHOH}), 2.50\left(\mathrm{tt}, 1 \mathrm{H}, J_{1}=12.9 \mathrm{~Hz}, J_{2}=3.5 \mathrm{~Hz}\right.$, $\mathrm{CH}-\mathrm{Ph}), 2.14-2.06(\mathrm{~m}, 2 \mathrm{H}$, hydrogens of cyclohexane ring), 1.98-1.90 (m, 2H, hydrogens of cyclohexane ring), 1.61-1.37 (m, $4 \mathrm{H}$, hydrogens of cyclohexane ring); ${ }^{13} \mathrm{C} \mathrm{NMR}\left(\mathrm{CDCl}_{3}, 100.6 \mathrm{MHz}\right)$ [29]: $\delta=146.7$, $128.5,126.9,126.2,70.8,43.6,36.1,32.6$; GC/MS (EI) $\mathrm{t}_{\mathrm{r}}=19.69 \mathrm{~min}: \mathrm{m} / \mathrm{z}(\%)=176\left(\mathrm{M}^{+}, 10\right), 158(100)$, 143 (90), 130 (60), 117 (50), 104 (75), 91 (60).

3.7. General Procedure for Lipase-Mediated Acetylation of cis- and trans-4-(tert-butyl)cyclohexan-1-ol (cis- and trans 3) (Semi-preparative Scale)

Compounds cis- and trans-3 (isolated from the semi-preparative ADH-mediated reductions) were added to a solution of MTBE $(9 \mathrm{~mL})$ and vinyl acetate $(1 \mathrm{~mL})$ together with CALA $(150 \mathrm{mg})$. The mixture was kept for $24 \mathrm{~h}$ in an orbital shaker $\left(160 \mathrm{rpm}, 30^{\circ} \mathrm{C}\right)$ and then concentrated in vacuo.

\subsubsection{Cis-4-(tert-butyl)cyclohexyl Acetate (cis-2)}

From compound cis-3 (460 mg, $2.95 \mathrm{mmol}$ ), derivative cis-2 was obtained (560 mg, 96\%): ${ }^{1} \mathrm{H}$ NMR $\left(\mathrm{CDCl}_{3}, 400 \mathrm{MHz}\right): \delta=4.99(\mathrm{~m}, 1 \mathrm{H}, \mathrm{CHOAc}), 2.05\left(\mathrm{~s}, 3 \mathrm{H}, \mathrm{CH}_{3} \mathrm{CO}\right), 1.96-1.90(\mathrm{~m}, 2 \mathrm{H}$, hydrogens of cyclohexane ring), $1.61-1.55\left(\mathrm{~m}, 2 \mathrm{H}\right.$, hydrogens of cyclohexane ring), $1.45\left(\mathrm{tt}, 2 \mathrm{H}, J_{1}=13.9 \mathrm{~Hz}, J_{2}=3.2\right.$ $\mathrm{Hz}$, hydrogens of cyclohexane ring), 1.33-1.23 (m, $2 \mathrm{H}$, hydrogens of cyclohexane ring), $1.02\left(\mathrm{tt}, 1 \mathrm{H}, J_{1}=\right.$ $\left.12.0 \mathrm{~Hz}, J_{2}=3.0 \mathrm{~Hz}, \mathrm{CH}-\mathrm{C}\left(\mathrm{CH}_{3}\right)_{3}\right), 0.86\left(\mathrm{~s}, 9 \mathrm{H}, \mathrm{C}\left(\mathrm{CH}_{3}\right)_{3}\right) ;{ }^{13} \mathrm{C} \mathrm{NMR}\left(\mathrm{CDCl}_{3}, 100.6 \mathrm{MHz}\right): \delta=170.8,69.6$, 47.8, 32.7, 30.8, 27.6, 21.8, 21.6; GC/MS (EI) $\mathrm{t}_{\mathrm{r}}=14.89 \mathrm{~min}: \mathrm{m} / \mathrm{z}(\%)=138\left(\mathrm{M}^{+}-60,29\right), 123(46), 82(86)$, 67 (71), 57 (100). Compound cis-2 was submitted to bulb-to-bulb distillation $\left(110-115^{\circ} \mathrm{C}, 10 \mathrm{mmHg}\right)$ to obtain a sample for olfactory evaluation.

\subsubsection{Trans-4-(tert-butyl)cyclohexyl Acetate (trans-2)}

From compound trans-3 (450 mg, $2.89 \mathrm{mmol})$, derivative trans-2 was obtained (540 mg, 94\%) $(460$ $\mathrm{mg}, 2.95 \mathrm{mmol})$, derivative trans-2 was obtained ( $540 \mathrm{mg}, 93 \%):{ }^{1} \mathrm{H} \mathrm{NMR}\left(\mathrm{CDCl}_{3}, 400 \mathrm{MHz}\right): \delta=4.61(\mathrm{tt}$, $\left.1 \mathrm{H}, J_{1}=11.3 \mathrm{~Hz}, J_{2}=4.4 \mathrm{~Hz}, \mathrm{CHOAc}\right), 2.01\left(\mathrm{~s}, 3 \mathrm{H}, \mathrm{CH}_{3} \mathrm{CO}\right), 2.05-1.95(\mathrm{~m}, 2 \mathrm{H}$, hydrogens of cyclohexane ring), 1.82-1.77 (m, 2H, hydrogens of cyclohexane ring), 1.34-1.24 (m, $2 \mathrm{H}$, hydrogens of cyclohexane ring), $1.15-0.96\left(\mathrm{~m}, 3 \mathrm{H}\right.$, hydrogens of cyclohexane ring $\left.+\mathrm{CH}-\mathrm{C}\left(\mathrm{CH}_{3}\right)_{3}\right), 0.84\left(\mathrm{~s}, 9 \mathrm{H}, \mathrm{C}\left(\mathrm{CH}_{3}\right)_{3}\right) ;{ }^{13} \mathrm{C} \mathrm{NMR}$ $\left(\mathrm{CDCl}_{3}, 100.6 \mathrm{MHz}\right): \delta=170.4,73.5,47.0,32.2,27.5,25.4,21.9,21.2 ; \mathrm{GC} / \mathrm{MS}(\mathrm{EI}) \mathrm{t}_{\mathrm{r}}=15.73 \mathrm{~min}: \mathrm{m} / \mathrm{z}(\%)$ $=138\left(\mathrm{M}^{+}-60,15\right), 123(30), 82(70), 67(55), 57(100)$. Compound trans-2 was submitted to bulb-to-bulb distillation $\left(115-120^{\circ} \mathrm{C}, 10 \mathrm{mmHg}\right)$ to obtain a sample for olfactory evaluation.

\subsection{Continuous-Flow Production of cis-4-isopropylcyclohexan-1-ol (cis-1)}

$280 \mathrm{~mL}$ of a buffer solution (phosphate buffer, $100 \mathrm{mM}, \mathrm{pH}$ 7) containing 2-propanol (20\% v/v), 4-isopropyl cyclohexanone $(4)(10 \mathrm{mM})$ and $\mathrm{NADH}(0.2 \mathrm{mM})$ were continuously fed to a stirred membrane reactor $\left(12 \mathrm{~mL}\right.$ reaction volume, $5 \mathrm{kDa}$ membrane cut-off, $\left.30^{\circ} \mathrm{C}\right)$ containing ADH200

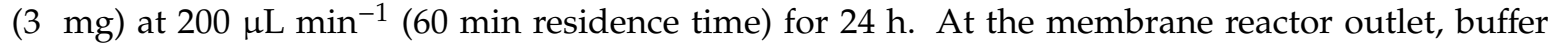
solution was mixed to $n$-hexane (fed at $200 \mu \mathrm{L} \mathrm{min}{ }^{-1}$ ) in a tee piece. The biphasic segmented flow thus formed entered a commercial in-line liquid-liquid separator (Zaiput ${ }^{\circledR}$, hydrophobic membrane OP-900). The two phases were then collected at the respective outlets. The total hexane solution collected in $24 \mathrm{~h}$ reaction time was submitted to solvent removal by in vacuo distillation to give cis-1 (3.66 g, 92\%) containing 5\% (GC/MS) of starting ketone 4 . 


\subsection{Continuous-Flow Production of cis-4-(tert-butyl)cyclohexyl Acetate (cis-2)}

Briefly, $280 \mathrm{~mL}$ of a buffer solution (phosphate buffer, $100 \mathrm{mM}, \mathrm{pH}$ 7) containing 2-propanol $(20 \% \mathrm{v} / \mathrm{v}), 4$-(tert-butyl) cyclohexanone (5) $(10 \mathrm{mM})$ and NADH $(0.2 \mathrm{mM})$ were continuously fed to a stirred membrane reactor $\left(12 \mathrm{~mL}\right.$ reaction volume, $5 \mathrm{kDa}$ membrane cut-off, $\left.30^{\circ} \mathrm{C}\right)$ containing ADH200 (3 $\mathrm{mg}$ ) at $200 \mu \mathrm{L} \mathrm{min}^{-1}$ (60 min residence time) for $24 \mathrm{~h}$. At the membrane reactor outlet, buffer solution was mixed to $n$-hexane (fed at $200 \mu \mathrm{L} \mathrm{min}^{-1}$ ) in a tee piece. The biphasic segmented flow thus formed entered a commercial in-line liquid-liquid separator (Zaiput ${ }^{\circledR}$, hydrophobic membrane OP-900). Aqueous phase was collected. Organic phase was continuously mixed with vinyl acetate (fed at $100 \mu \mathrm{L} \mathrm{min}-1$ ) in a tee piece. The resulting solution entered a column reactor packed with Candida antarctica lipase A (500 mg of dry weight, pre-swelled, column i.d. $6.6 \mathrm{~mm}, 30^{\circ} \mathrm{C}$ ) with a residence time of $11 \mathrm{~min}$. The total hexane solution collected in $24 \mathrm{~h}$ reaction time was submitted to solvent removal by in vacuo distillation to give cis-2 $(4.93 \mathrm{~g}, 89 \%)$ containing $4 \%$ (GC/MS) of starting ketone 5 and $10 \%$ (GC/MS) of intermediate alcohol cis-3.

\section{Conclusions}

Advantages connected to enzymatic transformations for the stereoselective production of fine chemicals are well established. In the field of functional perfumery, the availability of cheap and sustainable synthetic methods to the most odorous isomers of commercial fragrances is appreciated, not only to help reduce the environmental burden of manufacturing routes, but also to make available more performant products that can be employed in lower amounts in final products.

We report herein the case of leather alcohol and woody acetate: the odour thresholds of cis-isomers are respectively 5 and 10 times lower than those of the trans-isomer but, unfortunately, being less thermodynamically stable, they are hardly formed by reduction of the corresponding ketones with traditional reagents. The most selective chemical synthetic routes to cis-enriched samples reported in the literature are characterized by high environmental impact or delicate reaction conditions. For this reason, we wanted to explore alcohol dehydrogenases as a possible tool for a greener and more selective production of these two commercial fragrances. By submitting ketones 4 and 5 to ADHs from a commercial kit, we found that some of these enzymes were exceptionally active in providing the corresponding cis alcohols with high conversions (up to $99 \%$ ) and high de values (up to $99 \%$ ). In particular, ADH200 was selected for the preparation of $c i s-\mathbf{1}$ and 3 with de $=87 \%$ and $>99 \%$, respectively. We successfully tested also 4-methyl- and 4-phenyl-cyclohexanone $(6,7)$ to verify whether the same ADHs could be used on a wider range of differently substituted cyclohexanones (conversions: 85\%-99\%; cis-isomer de: 90\%-99\%).

Focusing on compound cis 2, we were able to select a second enzymatic step for acetylation of cis-3 (through lipase CALA in the presence of vinyl acetate), finally achieving a complete enzymatic synthesis of cis-2 (de $>99 \%)$ from ketone 5. To meet the demand of more efficient and automatic processes, we designed a completely continuous-flow process both for cis-1 and cis-2. We could couple in line enzymatic reduction and in line work-up for cis-1, with completely automatic synthesis and easy recovery of the product. Concerning production of $\mathrm{cis}-\mathbf{2}$, two biocatalytic reactions, requiring almost incompatible conditions, were successfully coupled. The continuous flow process allowed us, by means of in-line extraction and phase separation, to obtain the final product without intermediate isolation. Furthermore, processes were shown to be conveniently stable for $24 \mathrm{~h}$ in terms of conversion, confirming the potential of flow chemistry for biocatalytic applications.

Supplementary Materials: The following are available online at http://www.mdpi.com/2073-4344/10/1/102/ s1, Procedure for overexpression of GDH in E. coli BL21(DE3), Table S1: ADH-mediated reduction of 4-alkylcyclohexanones 4 and 5 to 4 -alkylcyclohexanols 1 and 3 (preliminary screening), Table S2: ADH-mediated reduction of 4-alkylcyclohexanones 6 and 7 to 4-alkylcyclohexanols 8 and $\mathbf{9}$ (preliminary screening).

Author Contributions: E.B., D.T. and F.T. conceived and designed the experiments; F.T., M.C. and M.C.G. performed the experiments and the structural characterization of compounds; E.B., D.T. and G.P.-F. analyzed the data; F.T. and E.B. wrote the paper. All authors have read and agreed to the published version of the manuscript. 
Funding: This research was funded by Fondazione Cariplo - INNOVHUB, project SOAVE (Seed and vegetable Oils Active Valorization through Enzymes), grant number 2017-1015.

Acknowledgments: The authors thank Philip Kraft (Givaudan Fragrances S\&T, Ingredients Research, Überlandstrasse 138, CH-8600 Dübendorf, Switzerland) for the odor descriptions.

Conflicts of Interest: The authors declare no conflict of interest.

\section{References}

1. Available online: http://www.thegoodscentscompany.com/data/rw1001961.html (accessed on 1 December 2019).

2. Available online: http://www.thegoodscentscompany.com/data/rw1001372.html (accessed on 1 December 2019).

3. Murugesan, K.; Senthamarai, T.; Alshammari, A.S.; Altamimi, R.M.; Kreyenschulte, C.; Pohl, M.-M.; Lund, H.; Jagadeesh, R.V.; Beller, M. Cobalt-Nanoparticles Catalyzed Efficient and Selective Hydrogenation of Aromatic Hydrocarbons. ACS Catal. 2019, 9, 8581-8591. [CrossRef]

4. Nie, Y.; Jaenicke, S.; van Bekkum, H.; Chuah, G.-K. Stereoselective cascade hydrogenation of 4-tert-butylphenol and p-cresol over Zr-zeolite beta-supported rhodium. J. Catal. 2009, 246, 223-231. [CrossRef]

5. Tan, S.-L.; Liu, G.-B.; Gao, X.; Thiemann, T. Raney Ni-Al alloy-mediated reduction of alkylated phenols in water. J. Chem. Res. 2009, 2009, 5-7. [CrossRef]

6. Hiyoshi, N.; Rode, C.V.; Sato, O.; Tetsuka, H.; Shirai, M. Stereoselective hydrogenation of tert-butylphenols over charcoal-supported rhodium catalyst in supercritical carbon dioxide solvent. J. Catal. 2007, 252, 57-68. [CrossRef]

7. Hiyoshi, N.; Sato, O.; Yamaguchi, A.; Rode, C.V.; Shirai, M. Kinetic analysis of 4-isopropylphenol hydrogenation over activated carbon-supported rhodium catalysts in supercritical carbon dioxide solvent. Green Chem. 2012, 14, 633-638. [CrossRef]

8. Brown, H.C.; Krishnamurthy, S.J. Lithium Tri-sec-butylborohydride. New Reagent for the Reduction of Cyclic and Bicyclic Ketones with Super Stereoselectivity. Remarkably Simple and Practical Procedure for the Conversion of Ketones to Alcohols in Exceptionally High Stereochemical Purity. J. Am. Chem. Soc. 1972, 94, 7159-7161. [CrossRef]

9. Bahia, P.S.; Jones, M.A.; Snaith, J.S. Al-Isopropoxydiisobutylalane: A Study of the Effect of Solvent on the Rate and Stereoselectivity of Cyclic Ketone Reduction. J. Org. Chem. 2004, 69, 9289-9291. [CrossRef]

10. Emura, M.; Toyoda, T.; Seldo, N.; Ikariya, T.; Ohkuma, T. Process for Producing cis-4-T-Butylcyclohexanol. U.S. Patent No. 5,856,590, 5 January 1999.

11. van Osselaer, T.A.; Lemière, G.L.; Lepoivre, J.A.; Alderweireld, F.C. Enzymatic in vitro reduction of ketones VI (1) Reduction rates and stereochemistry of the HLAD-catalyzed reduction of 3-alkyl- and 4-alkylcyclohexanones. Bull. Soc. Chim. Belg. 1980, 89, 133-149. [CrossRef]

12. Fitzpatrick, D.E.; Ley, S.V. Engineering chemistry for the future of chemical synthesis. Tetrahedron 2018, 74, 3087-3100. [CrossRef]

13. Poechlauer, P.; Colberg, J.; Fisher, E.; Jansen, M.; Johnson, M.D.; Koenig, S.G.; Lawler, M.; Laporte, T.; Manley, J.; Martin, B.; et al. Pharmaceutical roundtable study demonstrates the value of continuous manufacturing in the design of greener processes. Org. Process Res. Dev. 2013, 17, 1472-1478. [CrossRef]

14. Bennett, J.A.; Campbell, Z.S.; Abolhasani, M. Role of continuous flow processes in green manufacturing of pharmaceuticals and specialty chemicals. Curr. Opin. Chem. Eng. 2019, 26, 9-19. [CrossRef]

15. Rossetti, I.; Compagnoni, M. Chemical reaction engineering, process design and scale-up issues at the frontier of synthesis: Flow chemistry. Chem. Eng. J. 2016, 296, 56-70. [CrossRef]

16. Baumann, M.; Baxendale, I.R. The synthesis of active pharmaceutical ingredients (APIs) using continuous flow chemistry. Beilstein J. Org. Chem. 2015, 11, 1194-1219. [CrossRef] [PubMed]

17. Farkas, E.; Oláh, M.; Földi, A.; Kóti, J.; Éles, J.; Nagy, J.; Gal, C.A.; Paizs, C.; Hornyánszky, G.; Poppe, L. Chemoenzymatic Dynamic Kinetic Resolution of Amines in Fully Continuous-Flow Mode. Org. Lett. 2018, 20, 8052-8056. [CrossRef]

18. De Vitis, V.; Dall'Oglio, F.; Pinto, A.; De Micheli, C.; Molinari, F.; Conti, P.; Romano, D.; Tamborini, L. Chemoenzymatic synthesis in flow reactors: A rapid and convenient preparation of Captopril. ChemistryOpen 2017, 6, 668-673. [CrossRef] 
19. Brahma, A.; Musio, B.; Ismayilova, U.; Nikbin, N.; Siegert, P.; Jeromin, G.E.; Ley, S.V.; Pohl, M. An orthogonal biocatalytic approach for the safe generation and use of $\mathrm{HCN}$ in a multistep continuous preparation of chiral O-acetylcyanohydrins. Synlett 2016, 27, 262-266.

20. Delville, M.M.E.; Koch, K.; van Hest, J.C.M.; Rutjes, F.P.J.T. Chemoenzymatic flow cascade for the synthesis of protected mendelonitrile derivatives. Org. Biomol. Chem. 2015, 13, 1634-1638. [CrossRef]

21. Acetti, D.; Brenna, E.; Fuganti, C.; Gatti, F.G.; Serra, S. Enzyme-catalysed approach to the preparation of triazole antifungals: Synthesis of (-)-genaconazole. Tetrahedron Asymmetry 2009, 20, 2413-2420. [CrossRef]

22. Brenna, E.; Fuganti, C.; Gatti, F.G.; Parmeggiani, F. Enzyme-mediated synthesis of EEHP and EMHP, useful pharmaceutical intermediates of PPAR agonists. Tetrahedron Asymmetry 2009, 20, 2594-2599. [CrossRef]

23. Contente, M.L.; Farris, S.; Tamborini, L.; Molinari, F.; Paradisi, F. Flow-based enzymatic synthesis of melatonin and other high value tryptamine derivatives: A five-minute intensified process. Green Chem. 2019, 21, 3263-3266. [CrossRef]

24. Dall'Oglio, F.; Contente, M.L.; Conti, P.; Molinari, F.; Monfredi, D.; Pinto, A.; Romano, D.; Ubiali, D.; Tamborini, L.; Serra, I. Flow-based stereoselective reduction of ketones using an immobilized ketoreductase/glucose dehydrogenase mixed bed system. Catal. Commun. 2017, 93, 29-32. [CrossRef]

25. Vázquez, G.; Alvarez, E.; Navaza, J.M. Surface tension of alcohol + water from 20 to $50{ }^{\circ} \mathrm{C}$. J. Chem. Eng. Data 1995, 40, 611-614. [CrossRef]

26. Yang, C.; Wang, F.; Lan, D.; Whiteley, C.; Yang, B.; Wang, Y. Effects of organic solvents on activity and conformation of recombinant Candida antarctica A produced by Pichia pastoris. Process Biochem. 2012, 47, 533-537. [CrossRef]

27. Spiniello, M.; White, J.M. Low-temperature X-ray structural studies of the ester and ether derivatives of cisand trans-4-tert-butyl cyclohexanol and 2-adamantanol: Application of the variable oxygen probe to determine the relative $\sigma$-donor ability of $\mathrm{C}-\mathrm{H}$ and $\mathrm{C}-\mathrm{C}$ bonds. Org. Biomol. Chem. 2003, 1, 3094-3101. [CrossRef]

28. Wiitala, K.W.; Al-Rashid, Z.F.; Dvornikovs, V.; Hoye, T.R.; Cramer, C.J. Evaluation of various DFT protocols for computing ${ }^{1} \mathrm{H}$ and ${ }^{13} \mathrm{C}$ chemical shifts to distinguish stereoisomers: Diastereomeric 2-, 3-, and 4-methylcyclohexanols as a test set. J. Phys. Org. Chem. 2007, 20, 345-354. [CrossRef]

29. Hodgson, D.M.; Chung, Y.K.; Paris, J.-M. Intramolecular cyclopropanation of unsaturated terminal epoxides. J. Am. Chem. Soc. 2004, 126, 8664-8665. [CrossRef] 